\title{
Peel Ultrastructure During Developmental Stages of Citrus Sinensis (L.) Osbeck.
}

DOI 10.18196/pt.2014.017.1-11

\author{
Indira Prabasari
}

Program Studi Agroteknologi, Fakultas Pertanian, Universitas Muhammadiyah Yogyakarta, Jl. Lingkar Selatan,Kasihan, Bantul, Yogyakarta 55183; e-mail: sariindira@yahoo.com

\begin{abstract}
ABSTRAK
Struktur kulit jeruk Valencia (Citrus sinensis (L.) Osbeck] diuji menggunakan Scanning Electron Microscopy (SEM) dan menunjukkan bagian yang berbeda dari kulitnya: bagian luar berwarna kekuningan yang disebut flavedo dan bagian dalam kulit yang disebut albedo. Flavedo memiliki sel kompak dengan kelenjar minyak tertanam di dalamnya sedangkan albedo mengandung sel spons dengan ikatan pembuluh tertanam di dalamnya. Pengujian ultrastruktur dari albedo pada masa perkembangan menunjukkan perubahan morfologi albedo dari jaringan kompak menjadi jaringan yang longgar. Selain itu, distribusi polisakarida pada dinding sel diamati dengan pewarnaan histokimia dan kemudian distribusi polisakarida peptin dilakukan dengan menggunakan monoklonal antibodi anti-pektin (mAbs). Pewarnaan histokimia selama fase perkembangan menunjukkan perbedaan jumlah polisakarida pada tingkat jaringan. Selanjutnya, distribusi homogalacturonan (HG) dipelajari dengan menggunakan mAb JIM5 yang mengenali HG esterifikasi metil rendah dan JJM7 dengan label HG esterifikasi metil tinggi. Pengamatan pada buah dilakukan dengan menggunakan pencetakan jaringan dan hasilnya menunjukkan bahwa HG esterifikasi metil rendah dan tinggi didistribusikan hampir merata ke selurah bagian buah. Penelitian lanjutanpada tingkat jaringan dilakukan dengan menggunakan Light Microscopy (LM) dan menunjukkan bahwa HG ditemukan lebih banyak di dalam Albedo dan jaringan pembuluh diikuti oleh flavedo dan kelenjar minyak.

Kata kunci: Citrus sinensis, Ultrastruktur, Homogalacturonan
\end{abstract}

\begin{abstract}
The peel structureof Valencia orange [Citrus sinensis (L.) Osbeck] was examined using Scanning Electron Microscopy (SEM) and showed the distinct regions of the peel: the outer-yellowish part that was called the flavedo and the inner part of the peel that was called the albedo. The flavedo has compact cells with oil glands embedded in it whereas the albedo contains of spongy cells with vascular bundles embedded in it. The ultrastructural examination of the albedo during development revealed the changes of albedo morphology from compact tissue to the loosely arranged tissue. In addition, the distribution of polysaccharide cell walls was observed with histochemical staining and later the distribution of peptic polysaccharide was conducted using anti-pectin monoclonal antibodies (mAbs). Histochemical staining during development demonstrated the difference of abundance of polysaccharide at the tissue level. Furthermore, the distribution of homogalacturonan (HG) was studied with mAb JIM5 that recognizes low methyl-esterified HG and JJM7 which labels high methyl-esterified HG. The observation at the fruit level was conducted using tissue printing and the result showed that low and high methyl-esterified HG was distributed almost similar at the fruit level. Further experiment at the tissue level was performed using Light Microscopy (LM) and revealed that HG was found more abundant in the albedo and vascular bundle followed by the flavedo and oil gland.

Keywords: Citrus sinensis, Peel Ultrastructure, Homogalacturonan
\end{abstract}

\section{INTRODUCTION}

To date, many anti-pectin mAbs have been developed and used extensively on different tissue types of various plant species to study the distribution of pectin. Nevertheless the study of pectin in planta, particularly in orange fruits, is limited. We do not yet have a clear understanding of orange pectin with respect to its structure, or its location and modification during fruit development. Today, three major pectin polysaccharides are recognized: a fairly simple one called homogalacturonan (HG) which is composed entirely of GaIA; a rather more complex pectic polysaccharide called rharnnogalacturonan I (RG I) which contains 
GaIA, rharnnose (Rha), as well as a variety of other sugars as branches on the RG backbone, principally arabinan and galactan; and finally the most complex pectin polysaccharide of all, rharnnogalacturonan II (RG II) that also contains GaIA to which a complex array of side chains containing several unusual monosaccharides are attached (De Vries 1988; Schols 1995; Voragen 1995; Albersheim 1996)).

Citrus fruit development is divided into three different stages: stage I (cell division), stage II (cell enlargement) and stage III (fruit maturation) (Spiegel-Roy 1996). Stage I is also known as the cell division period. This stage begins two or three months after fruit set. However there is still no agreement about the commencement of stage I. One suggestion is that stage I begins at fruit set, immediately following anthesis whereas another suggestion is that stage I actually starts before anthesis due to the differences of the fruit size between leafy and leafless influorescences in the ovaries before anthesis (Guardiola 1987; Hofman 1988). Stage II is also called the cell enlargement phase that occurs during the next six months. Several developmental changes happen at this stage, including cell separation, enlargement and differentiation. Stage III is the ripening phase. At this stage the fruit reaches its maximum size and flavour although there still fruit growth during this period.

Studies have shown that in the cell wall, pectin is a dynamic structure being modified or degraded during developmental stages such as growth, abscission and ripening. The pectin network is influenced by specific developmental modifications such as cell wall swelling and fruit softening during ripening, cell separation during leaf and fruit abscission, pod dehiscence and root cap cell differentiation. Thus, it is likely that pectin has a huge impact upon cell functions and cell processes during development (Knox, 2002). The research aims to explore the ultrastructural details of orange peel using Scanning Electron Microscopy (SEM) and the distribution of homogalacturonan (HG) using specific monoclonal-antibodies (JIM5 and JIM7) during development of Citrus sinensis (L.) Osbeck. The distribution of HG was studied at the fruit level using tissue printing and further observation at the tissue level was performed with Light Microscopy (LM).

\section{MATERIALS AND METHODS}

Valencia oranges [Citrus sinensis (L.) Osbeck] used in this study were kindly provided by Dr. M. Treeby from the CSIRO Division of Plant Industry, Merbein (Mildura), Victoria, Australia. The oranges were picked according to their developmental stages (stage I, II and III), packed and immediately sent to The University of Melbourne where the research was conducted. The deliveries were received and fruit samples analysed on several occasions: December 2004, April 2005, November 2005 and August 2006. The oranges were stored in a cold room at $10^{\circ} \mathrm{C}$ prior to use in experiments.

\section{Scanning Electron Microscopy (SEM)}

Fixation of samples for SEM wasdone as follows: orange peels were fixed in $2.5 \%$ glutaraldehyde in 0,06 M PIPES buffer [piperazine-N Nbis (2-ethanesulfonic acid)] under a gentle vacuum for $2 \mathrm{hrs}$ at room temperature and then stored at $4^{\circ} \mathrm{C}$ overnight. Fixative was washed out by rinsing in PIPES buffer ( $3 \times 10 \mathrm{~min})$. The tissues were then post-fixed in $2.5 \%(\mathrm{v} / \mathrm{v})$ osmium tetroxide in PIPES buffer for $1.5 \mathrm{hrs}$ at room temperature. After washing in PIPES buffer ( $3 \times 10 \mathrm{~min}$ ), the tissues were dehydrated 
in a graded ethanol series [10\%, 20\%, 50\%, $70 \%, 90 \%$, and $100 \%$ (v/v; x3); 10 min for each step]. The Critical Point Dryer (CPD 030 from BAL-TEC Inc., Liechtenstein) was used to further dry the samples and the tissues were mounted on carbon-coated stubs and painted with silver liquid to enhance conductivity (Pro SciTech, Australia). Afterwards, the samples were coated with gold (Edwards Sputter Coater S150B) and then viewed with a Phillips XL30 Field-Emission Scanning Electron Microscope. Examinations with the SEM were conducted at three developmental stages, each stage using eight separate biological samples.

\section{Monoclonal antibodies}

The antibodies used were against low and high methyl-esterified homogalacturonans, the epitopes involved, together with their primary specificity have been previously described (Knox 1990; Willats2000). MAbs JIM5 and JIM7 were purchased from PlantProbes, UK.

\section{Tissue printing}

Valencia oranges were cut using sharp, nonserrated knife. The cut surfaces were then pressed firmly onto nitrocellulose papers dampened with Milli-Q water (Nitrobind, cast, pure nitrocellulose 0.22 micron, Osmonics Inc.) for approximately $20 \mathrm{~s}$. The prints were air dried for $1 \mathrm{hr}$, and the nitrocellulose papers were then blocked with 3\% (w/v) MP (Skim Milk Powder) I PBS (3.7 mM NaCl, $2.7 \mathrm{mM} \mathrm{KCl,} 4.3$ $\mathrm{mMNa}_{2} \mathrm{HPO}_{4}, 1.4 \mathrm{mMKH}_{2} \mathrm{PO}_{4}$, adjusted to $\mathrm{pH}$ 7.2) for $1 \mathrm{hr}$. Anti-pectin anti bodies (JIM5 and JIM7) diluted 1: IO in MP/PBS (Willats 1998) were added to the prints and then incubated at room temperature for 2 hrs. After washing extensively with PBS, goat-anti-rat-IgG-HRP (Pierce Biotechnology, USA) diluted 1:1000 in
MP/PBS was added and incubated for 1.5 hrs. The nitrocellulose papers were then washed thoroughly with Milli-Q water and antibody binding was detected by the addition of chloronaphthol-based substrates $(25 \mathrm{~mL}$ Milli-Q water, $5 \mathrm{~mL}$ methanol containing $10 \mathrm{mg} / \mathrm{mL}$ 4-chloro1-naphthol, $30 \mu \mathrm{L} 6 \%(\mathrm{v} / \mathrm{v}$ ) hydrogen peroxide, prepared immediately before use). When the blue colour appeared, the nitrocellulose papers were washed extensively with Milli-Q water. Control sections were treated in parallel but with the omission of the primary monoclonal antibodies. Tissue printing was performed at three developmental stages, each stage using eight separate biological samples.

\section{Fixation protocol}

The first part of the fixation protocol was the same as described previously. After dehydration with a graded ethanol series, the tissues were slowly infiltrated with LR White Resin over several days [25\% resin : $75 \%$ ethanol for $8 \mathrm{hrs;}$ 50\% resin: $50 \%$ ethanol overnight; $75 \%$ resin : $25 \%$ ethanol for $8 \mathrm{hrs}$; $100 \%$ resin (x3: overnight, $8 \mathrm{hrs}$ and overnight)]. The samples were then embedded in gelatin capsules, which were filled with fresh resin and polymerized overnight in an oven at $70^{\circ} \mathrm{C}$ (Craig and Miller, 1985).

\section{Staining for Light Microscopy (LM)}

Samples in resin blocks were trimmedon a Lei ca EM Trim and sectioned (1000 nm) on a Leica Ultracut R microtome (Vienna, Austria). The sections were collected onto glass microscope slides and dried on a hotplate. For mapping the distribution of anionic polysaccharides, the sections placed on glass microscope slides were stained with freshly prepared $0.02 \%(\mathrm{w} / \mathrm{v})$ ruthenium red in $1 \%(\mathrm{w} / \mathrm{v})$ aqueous ammonium acetate, and with $0.05 \%(\mathrm{w} / \mathrm{v})$ aqueous 
toluidine blue (Gane et al., 1994). I / KI reagent was used for detecting the presence of starch. Tissues were stained for $5 \mathrm{~min}$, rinsed in Milli-Q water and dried on a hotplate. A stock solution of $0.1 \%(\mathrm{w} / \mathrm{v})$ calcofluor white was used to label cellulose. Tissues were incubated for $30 \mathrm{~min}$, rinsed and mounted in 50\% glycerol. The images from LM were captured on Leica DC300F (Wetzlar, Germany) digital camera mounted on an Olympus compound microscope and processed using IM505 imaging program (Leica, Germany). The staining was done at three developmental stages, with each stage using eight different biological samples.

\section{Immunolabeling for Light Microscopy}

The immunolabeling was done as described by Meikle et al. (1994). Sections on glass microscope slides $(1000 \mathrm{~nm})$ were pre-incubated with 1\% (w/v) BSA (Bovine Serum Albumin) / PBS (3.7 mM NaCl, $2.7 \mathrm{mM} \mathrm{KCl,} 4.3 \mathrm{mM} \mathrm{Na}_{2} \mathrm{HPO}_{4}$, $1.4 \mathrm{mM} \mathrm{KH}_{2} \mathrm{PO}_{4}$, adjusted to $\mathrm{pH} 7.2$ ) for $30 \mathrm{~min}$ at room temperature to prevent non-specific antibody binding. Monoclonal anti bodies JIM5 and JIM7 were diluted in buffer (1:50; Clausen 2003). Diluted primary antibodies were applied to the sections, left for $1 \mathrm{hr}$ at room temperature and then kept at $4^{\circ} \mathrm{C}$ overnight. All sections were washed with PBS ( $2 \times 5$ min) and with $1 \%$ BSA/PBS ( $5 \times 5$ min) before incubation for 1 hr in a 1:20 dilution of anti-ratultra small gold (Aurion, Wageningen, The Netherlands). The sections were washed successively with PBS $(2 \times 5$ $\mathrm{min}$ ) and Milli-Q water (5x5 min), postfixed with 2.5\% glutaraldehyde in PBS for $5 \mathrm{~min}$ at room temperature. After further washing in Milli-Q water, Silver Enhancer and Developer (Aurion, mixed together in equal volumes) was applied to the sections and developed for $15 \mathrm{~min}$ in the dark. Sections were then washed with Milli-Q water and air dried. Control sections were treated in parallel but with the omission of the primary monoclonal antibodies. The labelling was done at three developmental stages, with each stage using eight different biological samples.

\section{RESULTS AND DISCUSSION}

The general morphological changes of orange fruit at stages I, II and III were examined before investigating fine details of the peel during development. Figures 1A, B show Valencia oranges on the tree at stage I, II and III. Cross and longitudinal sections of Valencia oranges showed clear changes at different developmental stages. The fruit at stage I was the smallest with its peel a dark green colour as shown in Figs. 2A, B. The diameter of fruit was approximately $2.8 \mathrm{~cm}$, with the peel approximately $0.8 \mathrm{~cm}$ in thickness. The locules attached to the central axis and young juice vesicles were projecting from the sides and from distal regions of the Jocular membrane. The peel at stageI consisted mainly of albedo and the oil glands appeared along the flavedo.The orange peel in fact, reaches its maximum width at or soon after the end of stage I (Holtzhausen 1981; SpiegelRoy 1996). The fruit at stage II had a lighter green colour with a diameter of approximately 6 $\mathrm{cm}$, and the peel thickness at this timehad decreased to- $0.6 \mathrm{~cm}$ (Figs. 2C,D). The proportions of albedo decreased at stage II, whereas the juice sacs enlarged. At stage II or the cell enlargement phase, which may also be envisaged as the pulp growth stage, there was a huge increase in pulp. The rapidly expanding pulp would exert considerable pressure outward on the peel, which as a consequence stretches and gets increasingly thinner progressively. According to Holtzhausen (1981), the changes are mechanical 

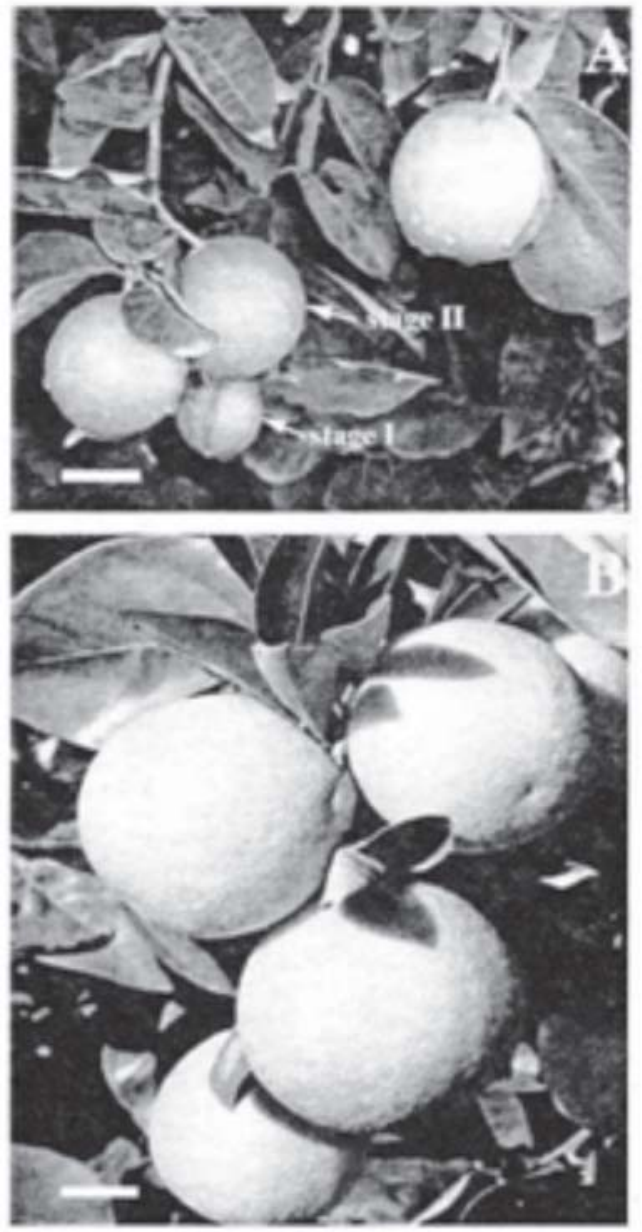

Figure 1 Valencia oranges on the tree at stages I, II (A) and III (B) (courtesy of Dr. Treeby). These pictures were taken at the orchard in Mildura (Victoria, Australia), from where the samples were obtained. These oranges were picked and sent immediately to The University of Melbourne where the research was conducted. Scale bar: $3 \mathrm{~cm}$
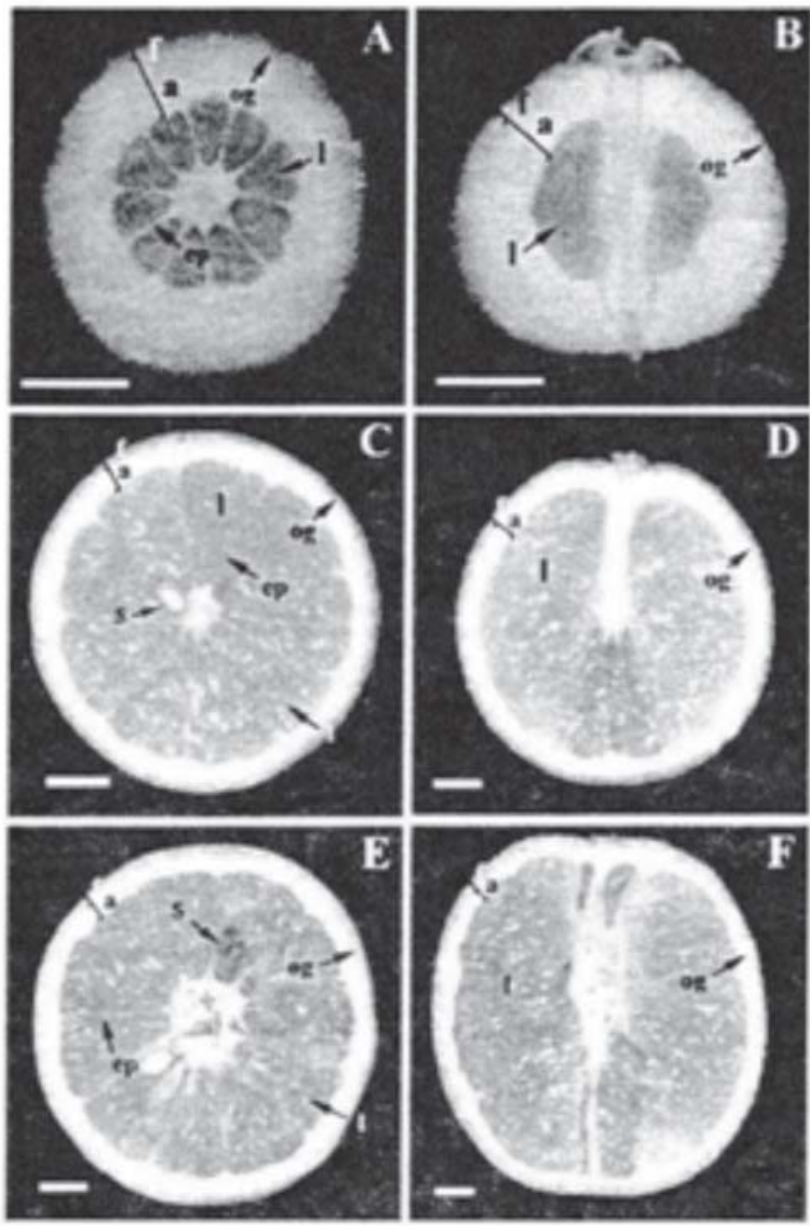

Figure2 Cross and longitudinal sections of Valencia oranges at Stage I (A, B). The diameter of fruit is approximately $2.8 \mathrm{~cm}$ and the peel has a dark green colour. The albedo is very thick at this stage, a total thickness of approximately $0.8 \mathrm{~cm}$ for the peel. Ten united radially carpels can be seen clearly at this stage. Cross and longitudinal sections of Valencia oranges at Stage II (C, D). The diameter of fruit is approximately $5.8 \mathrm{~cm}$. The juice sacs are juicier than Stage I and the colour has changed from green to yellow. The peel is approximately $0.6 \mathrm{~cm}$ in thickness with a light green colour. Cross and longitudinal sections of Valencia oranges at Stage III (E, F). The diameter of fruit is approximately $7.5 \mathrm{~cm}$. The juice sacs are full of fluid with an orange colour. The peel is approximately 0.6 $\mathrm{cm}$ in thickness and its colour has changed from light green to yelloworange. Scale bar = 1 cm. a, albedo; f, flavedo, l., locule, og, oil gland; s, seed. and due to the stretching of the peel. The fruit at stage III (or the mature stage) had an orange colour was approximately $7.5 \mathrm{~cm}$ in diameter, and the peel thickness was approximately 0.4 $\mathrm{cm}$. The pulp predominated at this stage while the albedo was quite thin as shown in Figs.2E, F.
The increase in fruit size from stage II to stage III was quite obvious, although the growth rate would depend to a large extent on climatic condition (Spiegel-Roy 1996).

The changes in peel pigment during developmental stages as shown in Fig.2 were due par- 

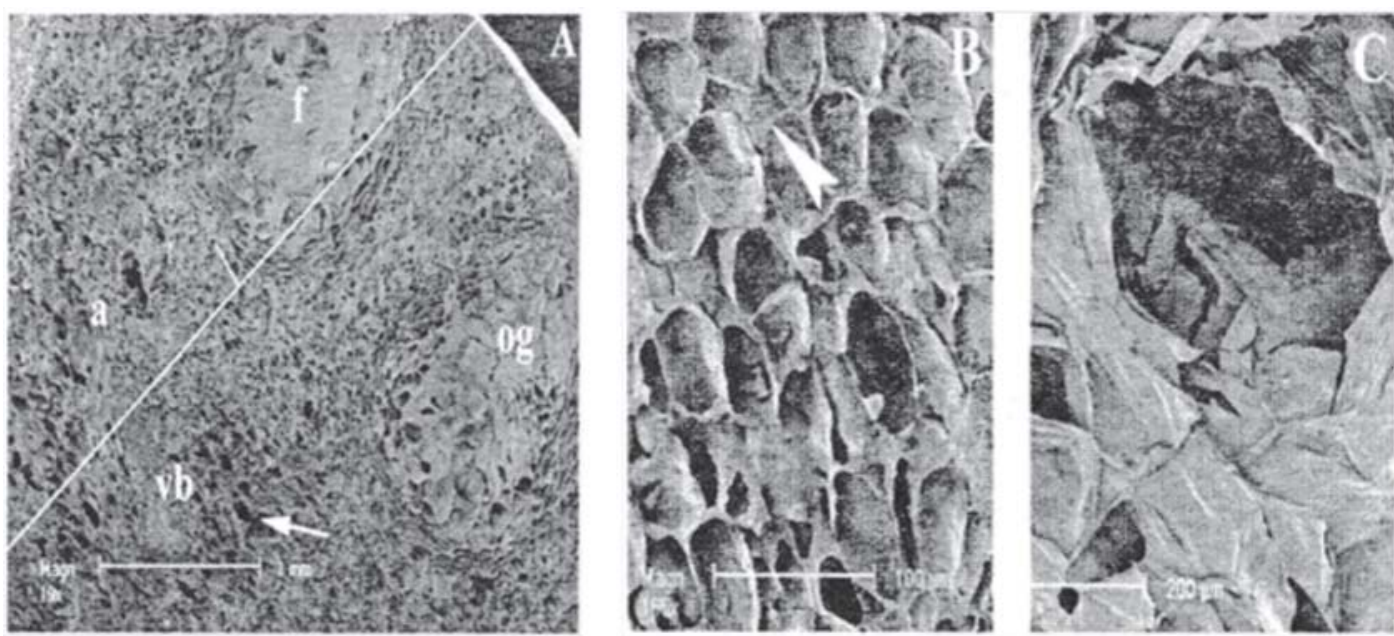

Figure 3 Scanning electron micrograph of fixed mature (Stage III) orange peel showing morphologically distinct regions (A) The flavedo has compact cells (8). The structure of oil gland (C). f, flavedo; a, albedo; vb, vascular bundle; og, oil gland; arrow: air space; arrow head: cell wall.

ticularly to the loss of chlorophyll (Braddock 1999). In addition, the mature orange fruit is known to contain relatively large amounts of a complex mixture of carotenoids. Some of these (e.g. cryptoxanthyne, â-citraurin) appear in small amounts but have a high tinctorial value (Gross 1984).

Further observation with the SEM of fixed orange peel sections was performed to unveil their ultrastructural details during development. Figure $3 \mathrm{~A}$ shows the morphologically distinct regions in mature orange peel: flavedo (epicarp), albedo (mesocarp), vascular bundle and oil gland. The flavedo, the external coloured portion of the peel, was compact and consisted of densely packed cells as shown in Fig. 3B. Flavedo has a wax coating that functions to protect the fruit in its natural environment. The flavedo contains oil gland tissue whose structure is shown in Fig. 3C. The oil glands serve as metabolic repositories for the terpenes and aromatic oils essential for the characteristic aroma and flavour of each type of fruit (Braddock 1999). Furthermore, the primary chemical constituent of these oils is the valued terpene, d-limonene. Beneath the flavedo is the albedo, the white part of the peel with the vascular bundles embedded in it. The structure of vascular bundle is shown in Fig. 4F. The albedo, the internal and white layer of the peel had cells that were loosely arranged and contained many air spaces which are needed for gas exchange (Carpita 2000), giving it a spongy texture (Figs. 4D, E). The albedo tissue, however, showed significant changes over different developmental stages. At stage I, the albedo tissue was very compact with essentially no intercellular air spaces (Fig. 4A). With the albedo achieving considerable expansion, the intercellular spaces became obvious (Fig. 4B). The very large intercellular spaces tended to form air cavities running radially through the tissue giving the albedo its characteristic spongy texture (Fig. 4C). These results are consistent with those reported previously (Storey 1994).

The general characteristics of orange peel were first examined using common histochemical stains for polysaccharides: ruthenium red, which is specific for acidic polysaccharides; toluidine blue, which is specific for polyanion 
(purple colour) and lignin (blue colour); iodine, which is specific for starch; and calcofluor white, which stains cellulose. The orange peel sections at all stages stained positively for acidic polysaccharides, polyanion, lignin, and cellulose, but were negatively for starch (Table 1; Figs. 5 and 6). Cellulose was found to be more intense at the vascular tissue (Fig. SA, B, C). This was not surprising because the presence of cellulose is higher in secondary walls (e.g. vascular tissue) (Carpita 2000).The intensity of staining is different between tissues during development. The acidic polysaccharides were found to be more intense at stage II and III. The observation with mAbs later on revealed that the intensity of pectin (low and high methyl-esterified HG) was increased during development. In addition, the acidic polysaccharides were more intense at the albedo tissue whereas lower intensity of staining was found at the tracheid (Fig. SD, E, F). The polyanion recognized by Toluidine blue staining showed that the oil gland had less polyanion as shown in Fig. $6 \mathrm{~B}$ than the albedo which had more (Fig. 6A, C). At stage III, the presence of lignin in vascular tissue was obvious (Fig. 6C). Lignin is the most common polyphenolic found in lignified secondary cell walls (e.g. vascular tissue) and functions to support mechanical strength (Cosgrove 2003). The presence of lignin in orangepeel was reported in previous studies (Braddock 1981). Starch was not found in orange peel at any developmental stages. The absence of starch is consistent with the previous report (Spiegel-Roy 1996).

At the fruit level, mAb JIM5, which recognizes low methyl-esterified HG epitope, bound abundantly throughout the Valencia orange fruit (Fig. 7A). It was predominantly in the albedo, endocarp partition and inner core of the fruit. Flavedo and oil glands however were

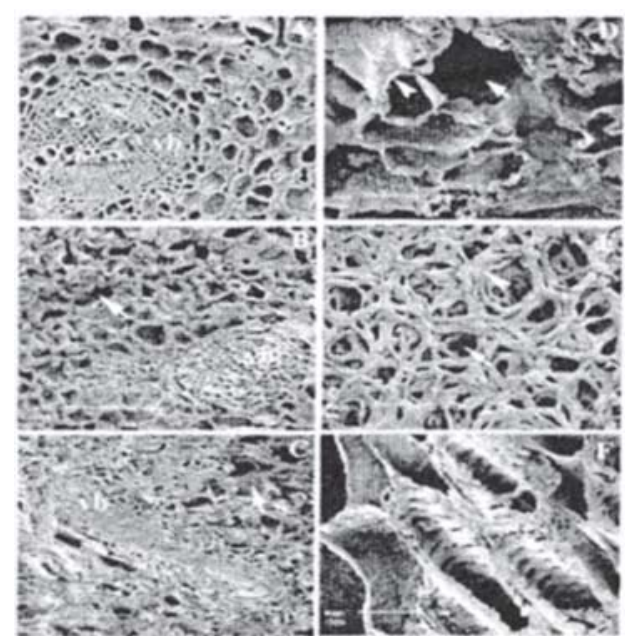

Figure 4 Scanning electron micrographs of fixed mature (Stage III) orange peel showing the difference of cell structure in the tissue and the development of albedo. The development of albedo started at Stage I when the albedo was quite compact with essentially no air spaces (A). At Stage II, albedo tissue had expanded and air spaces became obvious (B). At Stage III, the albedo was very spongy due to the presence of many and very large intercellular air spaces (C). The albedo has cells that are loosely arranged with many (and bigger) air spaces in cross section (D) and longitudinal section (E). The structure of vascular bundle (F). vb, vascular bundle; arrow: air space; arrow head: cell wall.
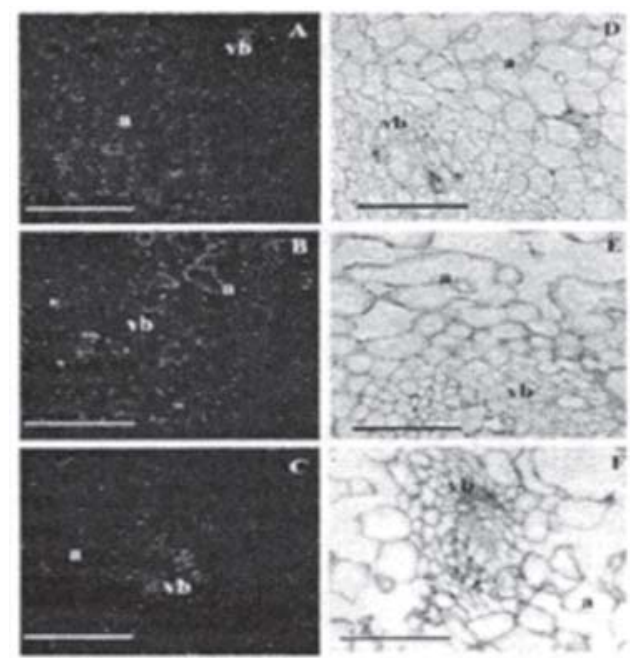

Figure 5 Light micrographs of fixed orange peel sections stained with calcofluor white at Stage I (A), Stage II (B) and Stage III (C). Light micrographs of fixed orange peel sections stained with ruthenium red at Stage I (D), Stage II (E), and Stage III (F). a, albedo; vb, vascular bundle; scale bar= $100 \mu \mathrm{m}$. 
Figure 6 Light micrograph of fixed orange peel sections blue at Stage I (A), oil gland at Stage II (B) and Stage III (C). a, albedo; vb, vascular bundle; scale bar= $100 \mu \mathrm{m}$. stained with Toluidine

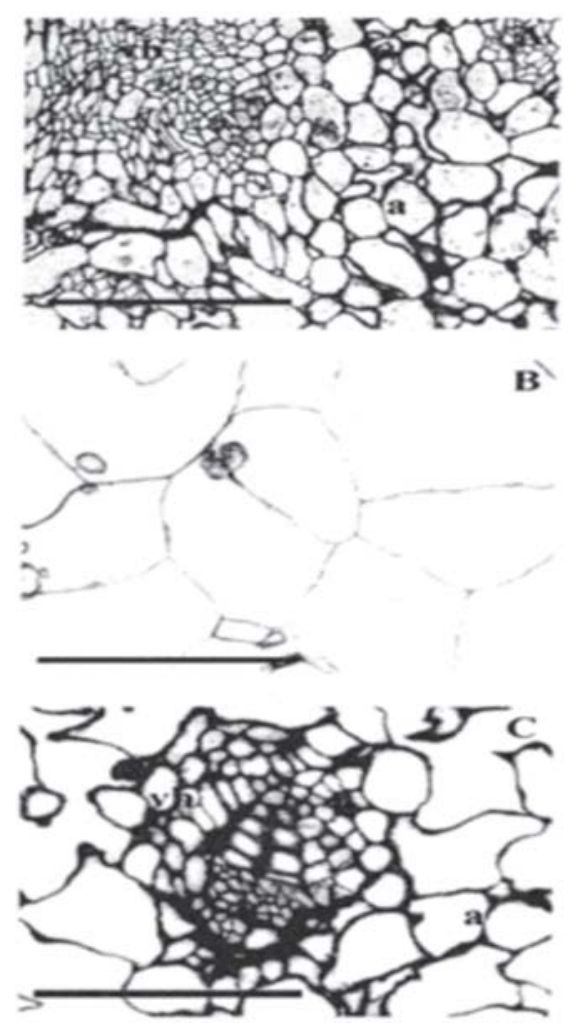

Figure 7 Tissue prints of mature orange fruits showing distribution of low methylesterified HG recognized by $\mathrm{mAb}$ JIM5 (A) and high methyl-esterified $\mathrm{HG}$ recognized by mAb JIM7 (B). a, albedo; f, flavedo; ep, endocarp partition; og, oil gland; js, juice sac; scale bar $=0.5 \mathrm{~cm}$. labelled relatively poorly. There was strong labelling of the outer layer of juice sacs but much less labelling inside the sacs.

The distribution was remarkably similar to the pattern reported for PME in orange fruit (Nielsen 2001). As PME catalysed the demethylesterification of cell wall polygalacturonan, and has been suggested to be involved in important developmental processes including cellular adhesion and stem elongation (Micheli 2001), it was not surprising to find that the distribution of low methyl-esterified $\mathrm{HG}$ matches that of PME in orange. It is difficult however to say that in those particular tissues (albedo, endocarp partition, the outer layer of juice sacs and inner core of fruit) HG would be composed mainly of low methyl-esterified HG, because high methyl-esterified HG was abundant in the same tissues. High methyl-esterified HG, which is labelled by mAb JIM7, was also present in the albedo and stronger labelling was found in the endocarp partition and inner core of the fruit (Fig. 7B). In contrast, the favedo and oil gland had less labelling.

Table 1 Staining properties of peel cell wall during developmental stages of Valenciaorange.

\begin{tabular}{lllll}
\hline STAIN & SPECIFICITY & STAGE I & STAGE II & STAGE III \\
\hline Ruthenium red & Acidic polysaccharide & +++ & +++ & +++ \\
Calcoflour white & Cellulose & +++ & +++ & +++ \\
Toluidine blue & Blue $=$ lignin & +++ & +++ & +++ \\
& Purple $=$ polyanion & & & \\
lodine & Starch & - & - & - \\
\hline
\end{tabular}

This result differs from the tissue print of lemon with mAb JIM7, in which high methylesterified HG was reported to be absent from exocarp (flavedo, oil gland) and the endocarp extension surrounding the juice sacs of lemon 
fruits (Willats 1998). However, lemon fruit had significant amounts of high methyl-esterified $\mathrm{HG}$ in the albedo, endocarp partition and inner core like the Valencia orange. In Valencia orange, high methyl-esterified HG was detected in the outer layer of juice sacs as well as inside the juice sacs but seemed to be absent in the layer between segments and the inner layer of albedo (Fig. 7B).

\section{CONCLUSIONS}

In summary, the ultrastructural studies of orange peel showed distinct difference in morphology between the tissues. The observation of albedo during development indicated the changes of albedo morphology from compact tissue to the loosely arranged tissue. Histochemical staining during development showed the difference of abundance of polysaccharide at the tissue level.

Tissue printing shows the different distribution of low and high methyl-esterified HG at the fruit level. At some degree, the distribution of these pectin polysaccharides differs from the distribution of pectin polysaccharides from lemon (Willats 1998). The difference of distribution between orange and lemon demonstrated that the location of pectin polysaccharides is different although the plants come from the same genus (Citrus L). The distribution of low methyl-esterified HG in Valencia orange was remarkably similar to the pattern reported for PME in orange fruit (Nielsen2001).

\section{REFERENCES}

Braddock, R. J. 1999. Handbook of citrus by-products and processing technology. New York, John Wiley and Sons, Inc.

Braddock, R. J., Crandall, P.G. 1981. Carbohydrate fibber from orange albedo (research note). J. Food Sci. 46: 650-654.

Carpita, N., McCann, M. 2000. The Cell Wall. Rockville, Maryland, American Society of Plant Physiologists.

Clausen, M. H., Willats, W.G.T. and Knox, J.P. 2003. Synthetic methyl hexagalacturonate happen inhibitors of antihornogalacturonan monnoclonal antibodies LM7, JIM5 and JIM7. Carbohydrate Research 338: 1797-1800.

Cosgrove, D. J. 2003. Expansion of the plant cell wall. Annu. Plant. Rev. 8 (Plant Cell Wall): 237-263.

De Vries, J. 1988. Repeating units in the structure of pectin. In Gums and stabilisers for the food industry. G. O. Philips, Wedlock, D.J. and William P.A. (eds.). Oxford, IRL. Press. 4: 2529.

Gross, K. C. 1984. Fractionation and partial characterization of cell walls from normal and non-ripening mutant tomato fruit. Physiol Plant 62: 25-32.

Guardiola, J. L. a. L., E. 1987. The effect of synthetic auxins on fruit and anatomical development in Satsuma mandarin. Sci. Hort 31: 119-130.

Hofman, P. J. 1988. Abscisic acid and gibberellins in the fruitlets and leaves of the Valencia orange in relation to fruit growth and retention. Sixth Int. Citrus Congr., Philadelphia, Balaban Publishers.

Holtzhausen, L. C. 1981. Creasing: formulating a hypothesis. Int. Soc. Citriculture, Shizuoka, japan, Okitsu Fruit tree Research station.

Knox, J.P. 2002. Cell and developmental biology of pectin. Oxford, Blackwell Publishing.

Knox, J. P., Linstead, P.J., King, J., Cooper, C., Roberts, K. 1990. Pectin esterification is spatially regulated both within cell walls and between developing tissues of root apices. Planta 181 : 512521.

Micheli,F.2001. Pectinmethylesterase: Cell wall enzymes with important roles in plant physiology. Trends Plant Sci. 6: 414419.

Nielsen, J. E. a. C., T.M.I.E. 2001. Distribution of pectin methyl esterase and acetylesterase in the genus Citrus visualized by tissue prints and chromatography. Plant Science 162:799-807.

Schols, H. A., Vierhuis, E., Bakx, E.J. and Voragen, A.G.J. (1995). Different population of pectin hairy regions occur in apple cell wall. Carbohydrate Res 275(2): 343.

Spiegel-Roy, P., Goldschmidt, Eliezer E. (1996). Biology of Citrus. Cambridge, Cambridge University Press.

Storey, R., Treeby, M.T. 1994. The morphology of epicutiliar wax and albedo breakdown cells of orange fruit in relation to albedo breakdown. Journal of Horticultural Science 69:329338.

Voragen, A.G. J., Pilnik, W., Thibault, J. F., Axelos, M.A.V., Renard, C.M.G.C (1995). Pectin. Food polysaccharides and their applications. A. M. Stephen. New York, Marcel Dekker: 287-339.

Willats, W. G. T., Marcus, S.E. and Knox, J.P. 1998. Generation of a monoclonal antibody specific to (15)-L-arabinan. Carbohydrate. Res. 308: 149-152.

Willats, W. G. T., Steele-King, C.G., McCartney, Lesley, Orfila, C., Marcus, S. E., Knox, J.P. 2000. Making and using antibody probes to study plant cell walls.Plant Physiol. Biochem 38; $27-$ 36. 

10 Planta Tropika Journal of Agro Science 
